\title{
Assessing population collapse of Drupella spp. (Mollusca: Gastropoda) 2 years after a coral bleaching event in the Republic of Maldives
}

\author{
L. Saponari (i) I. Dehnert • P. Galli $\cdot$ S. Montano
}

Received: 4 March 2020/Revised: 14 December 2020/Accepted: 4 February 2021/Published online: 4 March 2021

(C) The Author(s) 2021

\begin{abstract}
Corallivory causes considerable damage to coral reefs and can exacerbate other disturbances. Among coral predators, Drupella spp. are considered as delayer of coral recovery in the Republic of Maldives, although little information is available on their ecology. Thus, we aimed to assess their population structure, feeding behaviour and spatial distribution around 2 years after a coral bleaching event in 2016. Biological and environmental data were collected using belt and line intercept transects in six shallow reefs in Maldives. The snails occurred in aggregations with a maximum of 62 individuals and exhibited a preference for branching corals. Yet, the gastropods showed a high plasticity in adapting feeding preferences to prey availability. Drupella spp. were homogenously distributed in the study area with an average of $9.04 \pm 19.72 \mathrm{ind} / 200 \mathrm{~m}^{2}$. However, their occurrence was significantly different at the reef scale with the highest densities found in locations
\end{abstract}

Handling editor: Juan Carlos Molinero

L. Saponari $(\varangle) \cdot$ I. Dehnert · P. Galli · S. Montano Department of Earth and Environmental Sciences (DISAT), University of Milan - Bicocca, Piazza della Scienza, Milan 20126, Italy

e-mail: luca.saponari@unimib.it

L. Saponari · I. Dehnert · P. Galli · S. Montano MaRHE Center (Marine Research and High Education Center), Magoodhoo Island, Faafu Atoll, Republic of Maldives with higher coral cover. The impact of Drupella spp. appeared to be minimal with the population suffering from the loss of coral cover. We suggest that monitoring programs collect temporal- and spatialscale data on non-outbreaking populations or nonaggregating populations to understand the dynamics of predation related to the co-occurrence of anthropogenic and natural impacts.

Keywords Corallivory - Coral · Coral bleaching · Coral recovery $\cdot$ Predation $\cdot$ Acropora $\cdot$ Pocillopora

\section{Introduction}

Coral reefs are among the most diverse and dynamic ecosystems on the planet, and critically important for providing ecological goods and services to human communities (Williams et al., 2019; Woodhead et al., 2019). Yet, reefs are continuously deteriorating due to anthropogenic and natural disturbances such as global climate change, coral predators, and extreme weather events (De'ath et al., 2012; Hoegh-Guldberg et al., 2017; Hughes et al., 2017a, b; Rice et al., 2019). Knowing the scale of these impacts is essential for driving well-informed management decisions on reef conservation (i.e. Hughes et al., 2017a, b; Shaver et al., 2018). In particular, anthropogenic disturbances are reported to exacerbate the negative effects of coral 
predation (Rice et al., 2019). For example, the crownof-thorns seastar, Acanthaster spp., have been reported to cause high coral mortality during outbreaks, reducing coral cover up to $80 \%$ (Pratchett et al., 2014, 2017) with an increased effect during temperature-induced coral bleaching (Saponari et al., 2018). Other corallivores have been reported for the reduction in coral cover, among those, Drupella spp. feed exclusively on living coral tissue and is known to cause large-scale disturbances to coral reef ecosystems (e.g. Bruckner et al., 2017; Koido et al., 2017).

Drupella is a genus of marine gastropods comprising four species, Drupella cornus (Röding, 1798), D. eburnea (Küster, 1862), D. fragum (Blainville, 1832) and D. rugosa (Born, 1778) (Claremont et al., 2011). These tropical gastropods occur on coral reefs of the Indo-Pacific Ocean (Claremont et al., 2011) at low densities (0-2 ind $/ \mathrm{m}^{2}$; Cumming 1999, 2009a), although populations of Drupella spp. may display transitions between low density periods with outbreak and/or local aggregation events with up to $20 \mathrm{ind} / \mathrm{m}^{2}$ or 250 ind/colony, respectively (Cumming et al., 2009a; Bruckner et al., 2017).

Large aggregations of $D$. rugosa have been observed in the Indo-Pacific Ocean and are well documented on the Great Barrier Reef (Cumming, 1999), while outbreaks of Drupella spp. were reported from a wide range of regions including Kenya (McClanahan, 1994), Western Australia (Ayling \& Ayling, 1987), Hong Kong (Cumming, 1998; Morton and Blackmore, 2009), Red Sea (Antonious, A. \& B. Riegel, 1998), Thailand (Scott et al., 2017a, b) and India (Marimuthu \& Tripathy, 2018). These events appeared to be caused by overfishing of natural predators, high coral mortality and changes in temperature and salinity (Turner, 1994a, b; Cumming, 2009a, b), although the causes are complex and still not completely understood (McClanahan, 1994, 1997; Lam \& Shin, 2007; Ratianingsih et al., 2017). When these events occur, the damage on coral reefs may be severe reducing coral cover by 35 to $70 \%$ (Cumming, 2009a, b). Furthermore, impacts mediated by corallivores may synergically act with other coral stressors exacerbating coral mass mortality (Saponari et al., 2014, 2018; Pisapia et al., 2016, 2019) and delay reef recovery (Bruckner \& Coward, 2018). Thus, both outbreak and aggregation events may affect coral reef communities by reducing reef resilience and recovery (Lam \& Shin, 2007), causing population shifts and increasing disease incidences (Nicolet et al., 2013, 2018; Scott et al., 2017a, b). The feeding habits of these corallivores may also be influenced by the loss in coral abundance and diversity due to coral bleaching (Rice et al., 2019 and references included). For instance, Drupella spp. were reported changing dietary habits from the favourite genera Acropora and Pocillopora to the less palatable fungiid corals after a major coral bleaching event in Thailand (Hoeksema et al., 2013; Moerland et al., 2016).

Drupella spp. were recently reported to aggregate in the Republic of Maldives concurrent to the coral bleaching event in 2016 by Bruckner et al. (2017), but limited information is available prior to this event (see Taylor, 1978). The Republic of Maldives has been affected by a coral bleaching event in 2016 resulting in a loss of $30 \%$ and up to $95 \%$ of live coral cover (Perry \& Morgan, 2017; Pisapia et al., 2019). In addition, the Maldivian coral reef is threatened by increasing tourism and coastal development (Brown et al., 2017), land reclamation (Fallati et al., 2017) and natural stressors such as diseases (see Montano et al., 2012, 2015a, b, 2016; Seveso et al., 2012). Thus, both coral loss and recovery may vary between and within Atolls based on the different occurrence of disturbances (Zahir, 2000; McClanahan \& Muthiga, 2014; Pisapia et al., 2019), and consequently, variation in coral cover may differently influence the ecology and biology of associated organisms, such as corallivores.

The impact of corallivores in Maldives has recently started to attract scientific attention focusing on outbreaks of Acanthaster planci (Linnaeus, 1758) (Saponari et al., 2014, 2018), the ecology of Culcita spp. (Bruckner \& Coward, 2018; Montalbetti et al., 2019a, b) and the population dynamics of Drupella spp. after a bleaching event (Bruckner et al., 2017). However, very little information is available on the ecology of Drupella spp. in non-outbreaking or nonaggregating populations (Turner, 1994a; Cumming, 1999). Furthermore, the population dynamics of corallivores are still poorly described in the Maldives calling for more in-depth research. Here, we aim to explore the ecological traits of Drupella spp. In particular, we surveyed a population around 2 years after a mass coral bleaching event to examine the effects of variation in coral cover on the population structure, feeding behaviour and spatial distribution of Drupella snails. 


\section{Materials and methods}

Biological and environmental data collection

Although both species D. rugosa and D. cornus are reported from the Maldives (Taylor, 1978) the in-field identification was difficult since the shells of the specimens were often heavily encrusted with coralline red algae and different epifauna. Thus, to avoid misidentification, gastropod snails were identified to the genus level and considered as Drupella spp. (Fig. 1).

To examine the effects of variation in coral cover on Drupella spp. population structure, feeding behaviour and spatial distribution, we surveyed a total of 6 sites in two different Atolls (3 in Ari Atoll and 3 in Faafu Atoll) in the Republic of Maldives (Fig. 2) between November 2018 and March 2019. Sites were randomly selected according to accessibility and surveyed by snorkelling between 0 and $5 \mathrm{~m}$, in accordance with other studies that found Drupella spp. mainly in the shallower reefs (Taylor, 1978; Turner, 1994a; Cumming, 2009a, b; Hoeksema et al., 2013; Bruckner et al., 2017; Koido et al., 2017; Scott et al., 2017a, b; Hamman, 2018; Marimuthu \& Tripathy, 2018). To evaluate density variation within and among sites, belt transects of $200 \mathrm{~m}^{2}(50 \times 4 \mathrm{~m}$ each) were conducted both on the reef flat ( 6 transects at $0-2 \mathrm{~m}$ ) and along the reef crest (6 transects at $2-5 \mathrm{~m}$ ) in each site. The belt transects were randomly placed parallel to the shoreline and spaced 10-30 m apart. Each snail encountered in each belt transect was counted and removed from the position to avoid recount bias. In addition, size data was collected by measuring the long axis of each shell from the apex to the tip of the siphonal canal. The sizes were measured in the field to the nearest $\mathrm{mm}$, while the analysis and results were presented in $\mathrm{cm}$ for consistency with coral size data.

During the survey, the substratum directly beneath the snail was noted specifying the coral genus, size and morphology when the snail was found on a coral colony, or other substrata, such as coral rubble, dead coral or sand. Snails were considered 'preying' when associated with alive coral (i.e. over the living tissue or a dead part of a living coral colony in an aggregation or with a nearby feeding scar). In contrast, snails not associated with alive coral were considered 'moving'

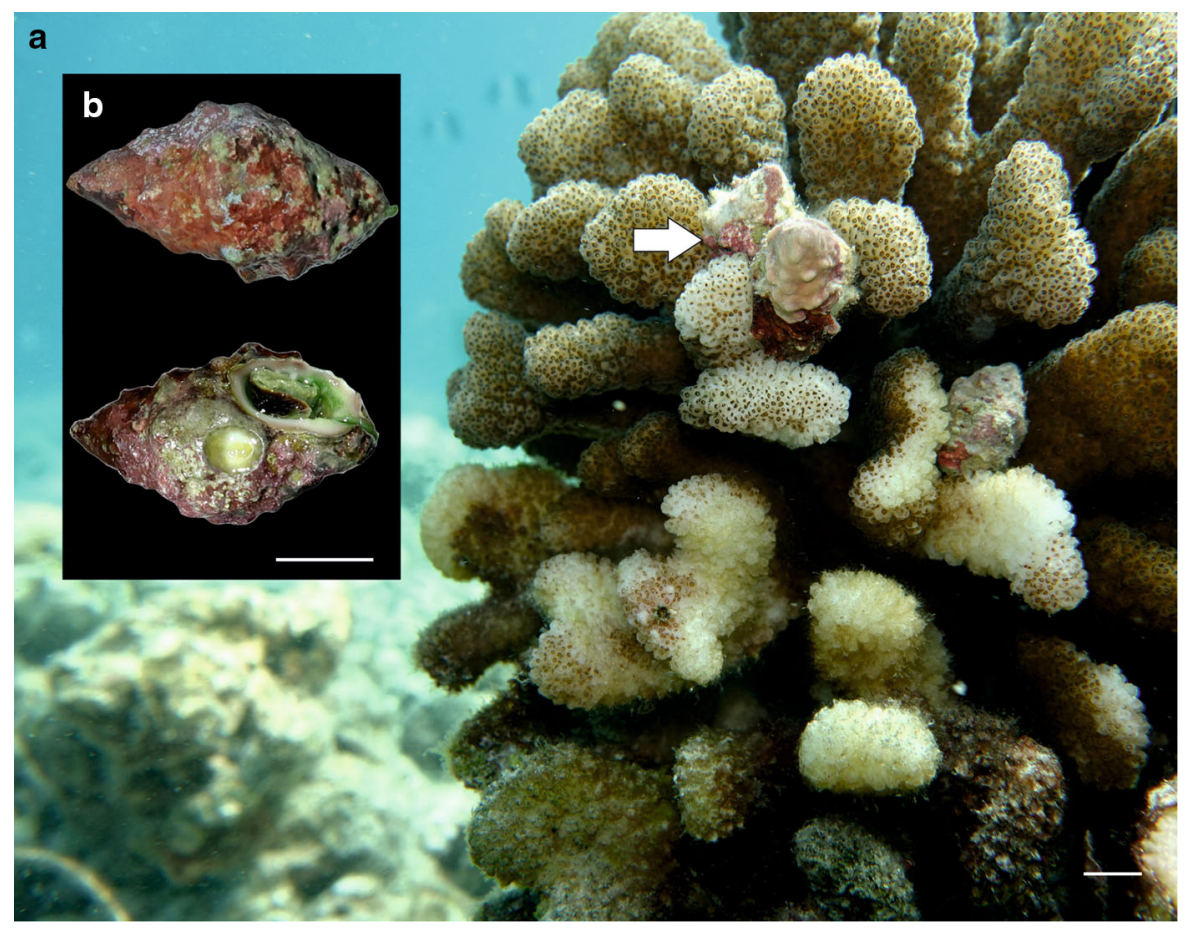

Fig. 1 a The picture was taken during the survey in Bathala. The specimens of Drupella spp. (highlighted by an arrow) were feeding on a colony of the genus Pocillopora. b Upper and lower view of Drupella spp., bars in a and $\mathbf{b}$ indicate $1 \mathrm{~cm}$ 


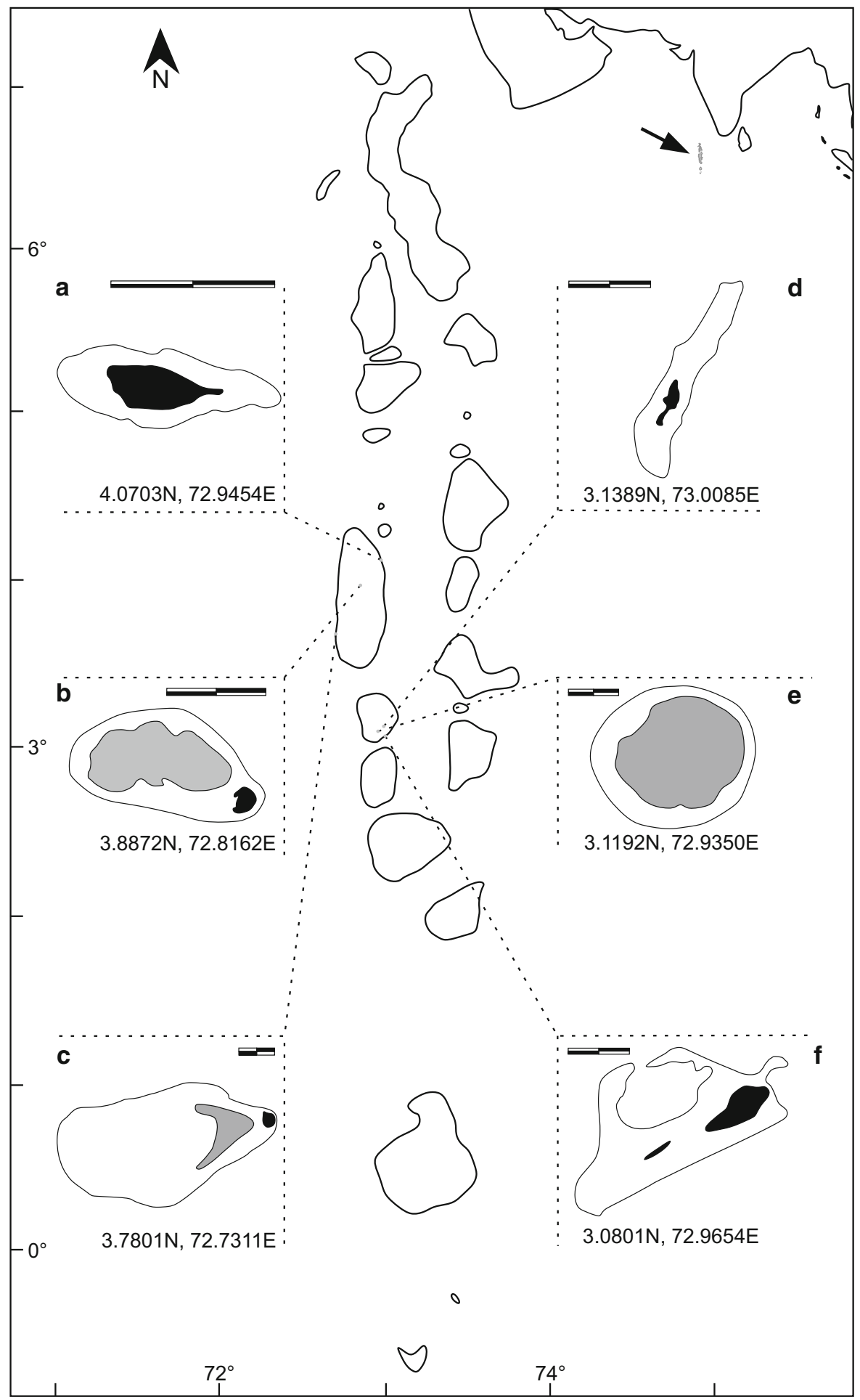

Fig. 2 Map of the study area located in Ari and Faafu Atolls in the Republic of Maldives (black arrow). a Bathala, b Athuruga, c Thudufushi (Ari Atoll), d Adhanga, e Maaga and f Magoodhoo
(Faafu Atoll). Solid lines represent reef limits, in black the islands and in grey the closed lagoon. Total scale bars are $0.5 \mathrm{~km}$ 
based on the concept that they need to move from one coral colony to the other to find shelter and food (Cumming, 1999; Morton et al., 2002). Further, we measured the maximum diameter of the scar area and the coral colony were measured. The scar size was then divided in two categories, specifically $>50 \%$ or $<50 \%$ of the size of the coral colony. Data for the abundance of corals in the sites was collected by using the Line Intercept Transect (LIT) method with three $10 \mathrm{~m}$ long transects spaced $10 \mathrm{~m}$ apart, on the same belt transect used for abundance and size structure of Drupella spp. Benthic categories were selected following Saponari et al. (2018).

\section{Statistical analysis}

Drupella spp. size data was pooled into three classes comprising recruits $(<1 \mathrm{~cm})$, juveniles $(1-2 \mathrm{~cm})$ and adults $(>2 \mathrm{~cm})$, following Turner (1994a, b). The Hartigan's dip test (Hartigan \& Hartigan, 1985) was used to test the size distribution for unimodality in order to assess the presence of a multiple (i.e. nonunimodal) or single (i.e. unimodal) recruitment event (see Saponari et al., 2018). The statistical analysis was performed using RStudio (R Core Team, 2017) with the dip.test package (Maechler, 2016).

Furthermore, we investigated the feeding preferences of Drupella spp. The Ivlev's (1961) electivity index $\left(E_{\mathrm{i}}\right)$ was used with the formula:

$E_{\mathrm{i}}=\left(r_{\mathrm{i}}-p_{\mathrm{i}}\right) \div\left(r_{\mathrm{i}}+p_{\mathrm{i}}\right)$.

For this equation $r_{i}$ represents the proportion of prey in the diet and $p_{i}$ represents the proportion of prey in the environment. Values of $E_{\mathrm{i}}$ range between 1 (maximum preference) and -1 (maximum avoidance), whereby 0 indicates random feeding. We calculated $r_{i}$ as the frequency of snails on a specific $i$ genus or family of corals in relation to all the preyed colonies. After, we obtained $p_{i}$ as the mean relative abundance of each single genus or family of corals in the environment.

Statistical comparisons of the spatial variation, number of snails per aggregation within genera, morphology, locations, differences in shell size between locations and differences in coral cover between locations were analysed using the MannWhitney $U$-test and the Kruskal-Wallis test with Tukey's post hoc test because data failed in meeting the normality assumption (Zar, 1999). Comparisons within coral genera occupied by Drupella spp., the number of snails per aggregations and the occurrence of aggregations on different coral morphologies, genera and locations were analysed with $\chi^{2}$ goodness-of-fit tests. Spearman's rank correlation was used to examine whether the density of Drupella spp. was related to benthic categories and to the number of genera on each location. This allowed us to verify which variables among benthic coral or occurrence of genera drive Drupella spp. density. Further, a simple linear regression was used to examine the relationship between coral cover and snail density variation by plotting the number of snails and the average coral cover for each $50 \mathrm{~m}$ transect, across sites. Statistical analysis was performed using SPSS ver. 24 (IBM, New York). All data is represented as arithmetic means \pm standard deviation.

\section{Results}

Drupella spp. population structure

Shell size was measured for all the individuals, ranging from 0.2 to $4.8 \mathrm{~cm}$, and yielding a mean value of $2.62 \pm 0.53 \mathrm{~cm}$. The resulting population structure was not unimodal as determined by the dip test $\left(P<2.2 \times 10^{-16}\right)$. The snail population was constituted mainly by adults $(>2 \mathrm{~cm}$ ) with $90.3 \%$ of the individuals, while only $9.1 \%$ were juveniles $(1-2 \mathrm{~cm})$ and $0.6 \%$ were recruits $(<1 \mathrm{~cm})$ (Fig. 3). Snail size was significantly larger in Faafu than Ari atoll $(U=79,998, z=2,383, P<0.001)$ as well as on the reef crest compared to the reef flat considering the data pooled $(U=51,246, z=2,231, P=0.027)$. The analysis revealed a significant difference between locations $(\mathrm{K}-\mathrm{W}, P<0.001)$. The post hoc test suggested that Magoodhoo had bigger snail sizes compared to Bathala, Thudufushi and Adhanga, as well as Adhanga compared to Thudufushi $(\mathrm{K}-\mathrm{W}, P<0.05)$.

Feeding behaviour

Prey preferences changed in different locations following the availability of coral prey. Pocillopora had a positive index value for Bathala, Thudufushi, Adhanga and Maaga, while Acropora for Bathala and Thudufushi and Porites for Athuruga and Magoodhoo. The genus Pavona had a positive index 
Fig. 3 Distribution of Drupella spp. divided into size classes following Turner (1994a, b)

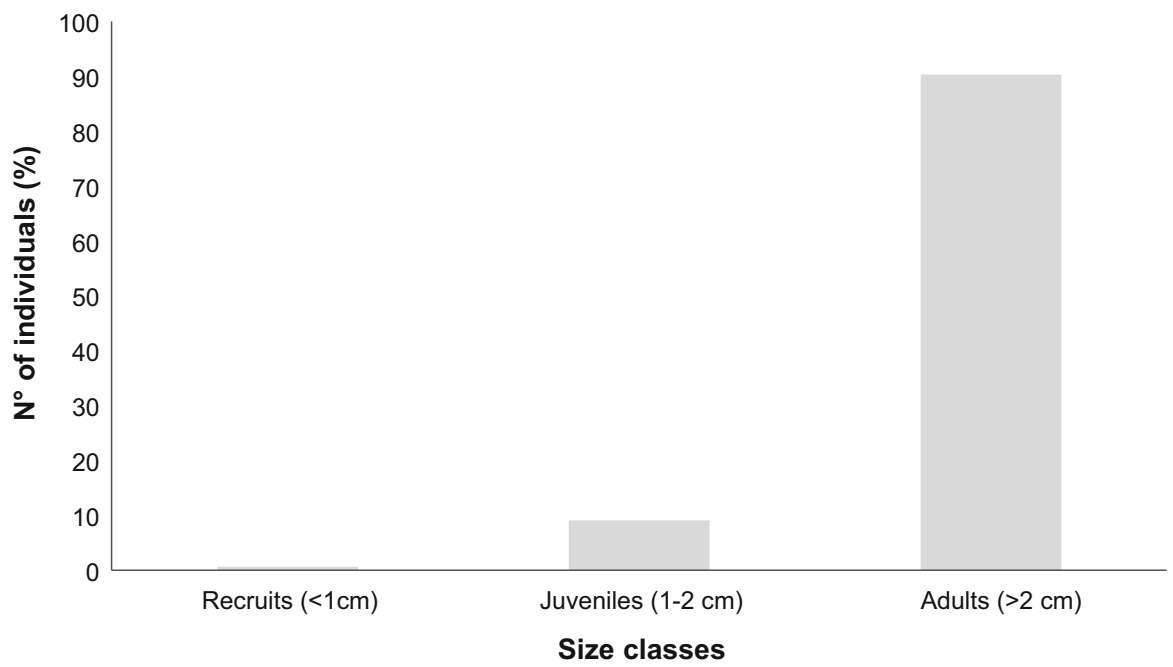

only for Bathala and the genus Hydnophora only in Adhanga. In all other cases negative values indicated avoidance (Table 1). Looking at the pooled data, the electivity index $\left(E_{\mathrm{i}}\right)$ showed a positive value, by meaning preferred, for the genera Pocillopora and Acropora, 0.35 and 0.17 respectively, while random choice resulted for Porites with an electivity index of 0.002 . We observed negative electivity values for Pavona and Hydnophora, -0.75 and -0.79 respectively (Fig. 4). In addition, the predation was not found to be lethal at the moment of the survey, since $82 \%$ of the occupied colonies were damaged by less than $50 \%$ of the colony size and only 1 colony was found dead.

The size of the preyed upon coral colony varied from 8 to $500 \mathrm{~cm}$ in maximum diameter. The size class most represented was $25-35 \mathrm{~cm}(17.9 \%)$, followed by $15-25$ and $35-45 \mathrm{~cm}(15.4 \%$ and $10.9 \%$, respectively). Notably, no individuals of Drupella spp. were found preying upon coral recruits $<5 \mathrm{~cm}$ in maximum diameter, despite their occurrence in every location.

Individuals of Drupella spp. were mostly found on live coral colonies $(85.6 \%)$, although few individuals were found on dead corals $(13.2 \%)$ and coral rubble (1.2\%). Overall, $92 \%$ of the snails were classified as "preying", while the remaining $8 \%$ were considering moving, likely searching for other coral colonies. The snails were found on 232 colonies of corals, and considering the whole dataset pooled, the genus Porites was the most frequently occupied (43.7\%) followed by Pocillopora (33.4\%), Acropora (22.4\%), Pavona (1\%) and only 1 individual was found on a single colony of the genus Hydnophora $\left(\chi_{(4)}^{2}=440.708, P<0.001\right)$.

Drupella spp. were found aggregating on $54.7 \%$ of the colonies, with a minimum of 2 and a maximum of 62 individuals (Fig. 5), which were found on a single

Table 1 Feeding preferences of Drupella spp. according to the Ivlev's Electivity Index $\left(E_{\mathrm{i}}\right)$ considering the genera preyed upon at each location

\begin{tabular}{lrcccc}
\hline & Porites & Acropora & Pocillopora & Pavona & Hydnophora \\
\hline Bathala & -0.77 & 1.00 & 0.75 & 0.45 & -1.00 \\
Athuruga & 0.79 & -1.00 & -1.00 & -1.00 & -1.00 \\
Thudufushi & -0.80 & 0.26 & 0.44 & -0.39 & -1.00 \\
Adhanga & -0.24 & -0.02 & 0.59 & 0.24 & n.d \\
Maaga & -1.00 & -1.00 & -0.64 & -1.00 & -1.00 \\
Magoodhoo & 0.17 & -0.16 & 0.00 & \\
\hline
\end{tabular}

The genera Pavona and Hydnophora were absent in Maaga, thus no data (n.d.) were reported 
Fig. 4 Feeding preference of Drupella spp. according to the Ivlev's Electivity Index $\left(E_{\mathrm{i}}\right)$ for each genera or family pooled in the study area

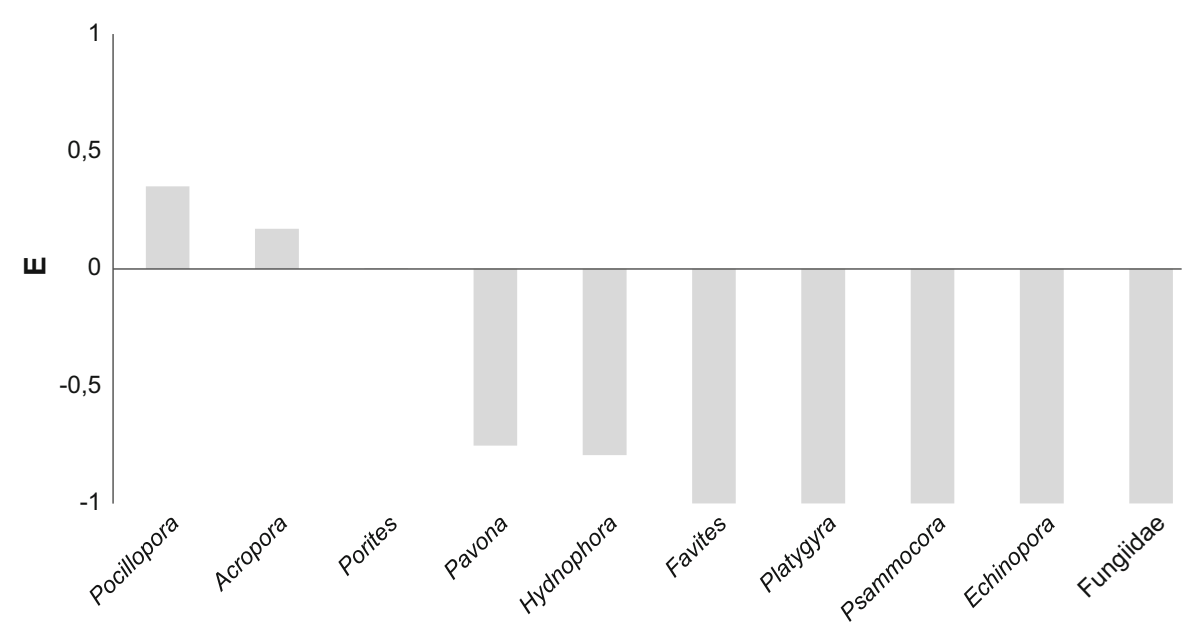

branching colony of the genus Acropora. Aggregations constituted of a few individuals, with an average of $5.63 \pm 7.1$ ind per aggregation and the majority in between 2 and 5 individuals $\left(\chi_{(15)}^{2}=125.455\right.$, $P<0.001)$. The data showed non-significant differences in number of individuals per aggregation within different coral genera $(\mathrm{K}-\mathrm{W}, P=0.336)$, morphology (K-W, $P=0.104)$ nor for locations $(\mathrm{K}-\mathrm{W}$, $P=0.085)$. Thus, the number of individuals was randomly distributed among four genera of corals (Porites spp., Acropora spp., Pocillopora spp. and Pavona spp.) and there was no preference in morphology nor in locations. Furthermore, Drupella spp. were aggregated more frequently on branching corals $(79.8 \%)$ than massive $(5.6 \%)$, digitate $(12.4 \%)$ or encrusting $(2.2 \%)\left(\chi_{(3)}^{2}=144.303, P<0.001\right)$. The aggregations occurred more frequently on Porites (49.4\%) than Pocillopora (33.7\%), Acropora (14.6\%) and Pavona $(2.2 \%)\left(\chi_{(3)}^{2}=46.236, P<0.001\right)$ and more frequently in Magoodhoo $\left(\chi_{(4)}^{2}=75.931\right.$, $P<0.001)$ than other locations.

\section{Spatial distribution}

During the study period, the monitoring survey for the population of the snail Drupella spp. was performed with a total of 72 transects covering an area of 1.44 ha. We counted 651 individuals of Drupella spp. with an overall mean density of $9.04 \pm 19.72 \mathrm{ind} / 200 \mathrm{~m}^{2}$. The distribution of the snail was homogeneous at a large spatial scale, as highlighted by the $U$-test, which showed non-significant differences in densities
Fig. 5 Distribution of the percentage of aggregations following the number of individuals per aggregation

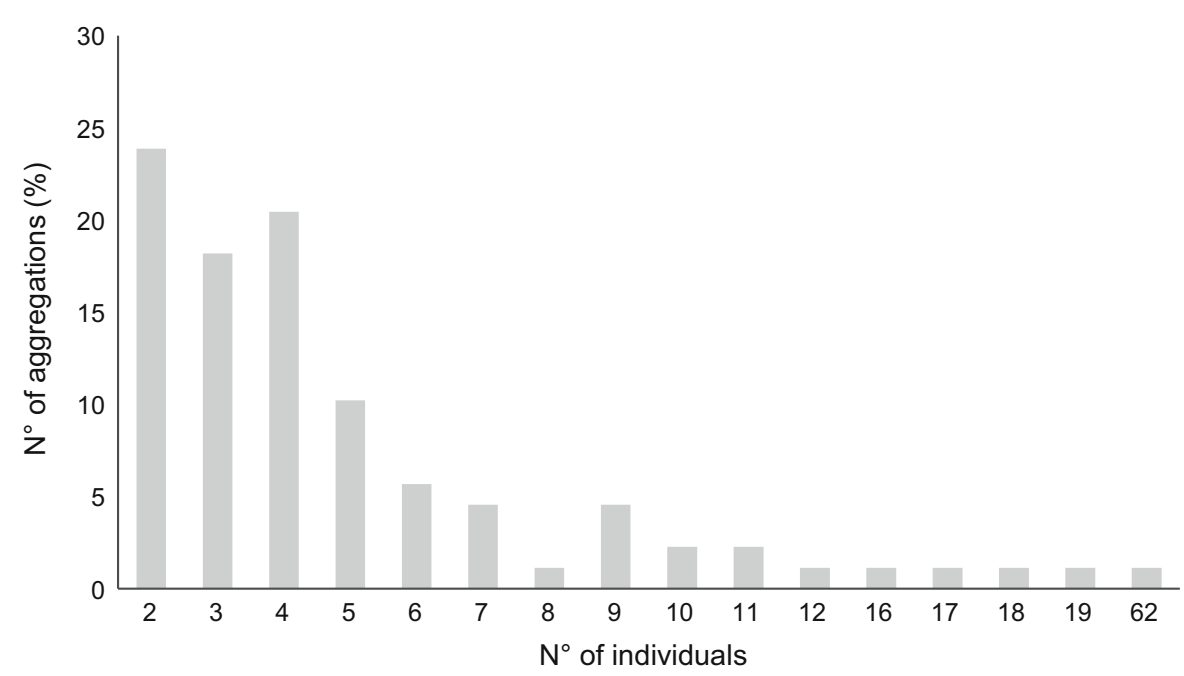


between Ari and Faafu Atoll $(U=741.5, z=1.103$, $P=0.270$ ). Similarly, no significant differences were found comparing the density of individuals on the flat and the crest reef area $(U=762, z=1.351$, $P=0.177)$ and the comparison within flat and crest area in each location ( $U$-test, $P>0.05$ for all comparisons). Contrarily, at the location scale, the distribution of individuals varied significantly (Fig. 6a). Thudufushi, Magoodhoo and Adhanga presented the highest densities with $22.8 \pm 26.9$, $22.3 \pm 33.3$ and $5.25 \pm 5.6 \mathrm{ind} / 200 \mathrm{~m}^{2}$ respectively, while Drupella spp. occurrence was lowest in Athuruga with $0.25 \pm 0.9 \mathrm{ind} / 200 \mathrm{~m}^{2}(\mathrm{~K}-\mathrm{W}, P<0.001)$.

The data on coral cover, from 216 LIT pooled, showed that benthic coverage was mostly dominated by dead corals $(50.2 \% \pm 29.9)$ and coral rubble $(35 \% \pm 30.4)$ with alive coral coverage accounting for $8.6 \% \pm 13.2$. Further, coverage of live coral was significantly different between locations (K-W, $P<0.001$; Fig. 6b) with Magoodhoo, Thudufushi and Adhanga showing the highest values $(14.5 \% \pm 18.1,13.9 \% \pm 9.4,13 . \% \pm 9.2$, respectively) and Maaga showing the lowest $(0.7 \% \pm 1.3)$.
Yet, there was a significant positive correlation between density of Drupella spp. and live coral coverage (Spearman's rho $\rho=0.546, P<0.001$ ), while, the number of genera in each location did not correlate significantly with the density of Drupella spp. (Spearman's rho $\rho=0.771, P=0.72$ ). Snail density was also negatively correlated with the presence of macroalgae (Spearman's rho $\rho=-0.330, P=0.005$ ) and dead coral (Spearman's rho $\rho=-0.266, P=0.024)$. Furthermore, a significant regression equation was found $\left(F_{(1,70)}=71.393\right.$, $R^{2}=0.5049, P<0.001$, Fig. 7) showing that around $50.5 \%$ of the variation in number of snails was explained by the variation in average coral cover per transect, across sites.

\section{Discussion}

Drupella spp. population structure

Size structure of the population surveyed revealed a dominant proportion of adults compared to juveniles
Fig. 6 a Data showing the differences in snail density for each location and b average coral cover in percentage for each location. Bars indicate standard deviation

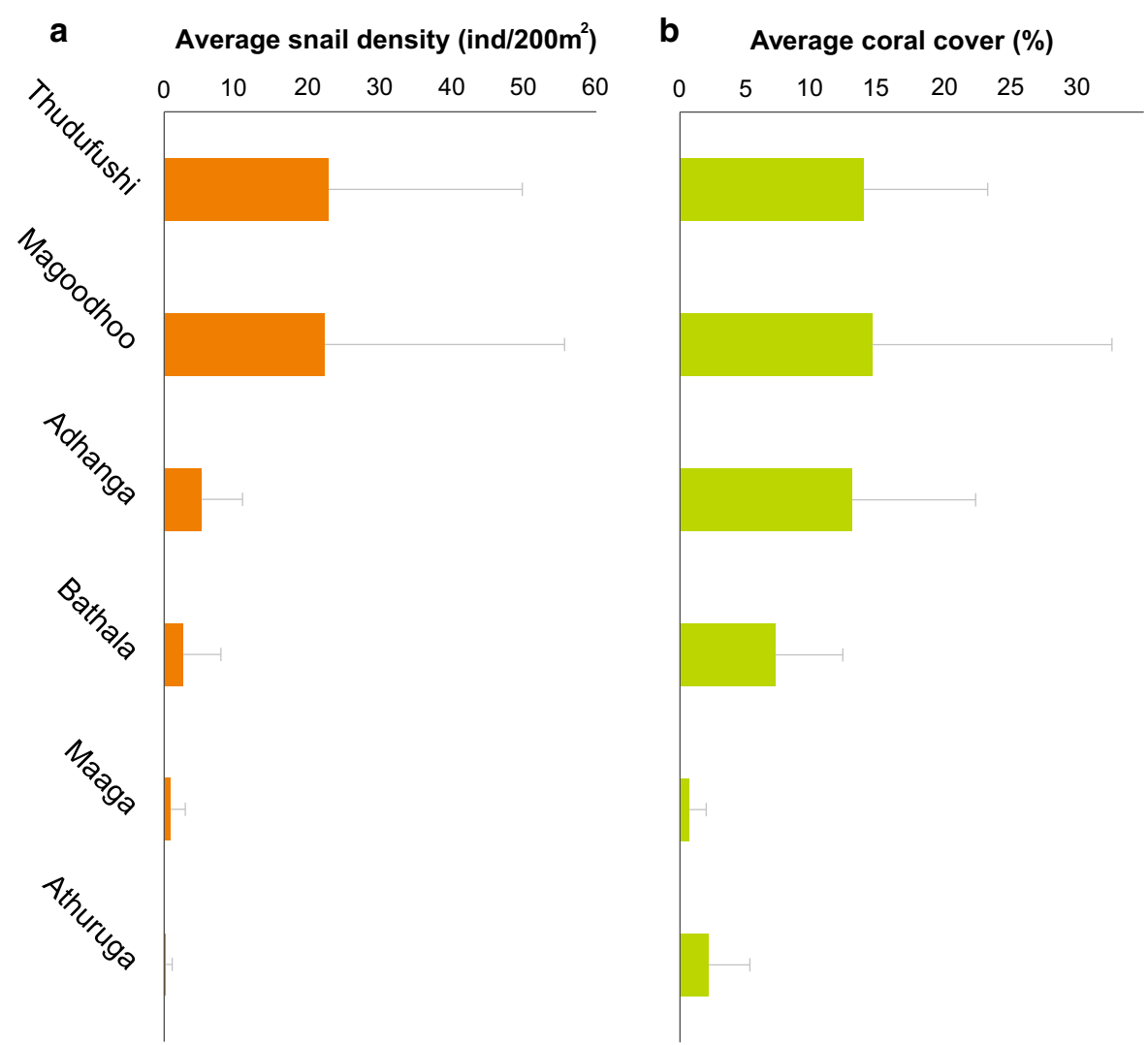


Fig. 7 Relationship between number of snails and average coral cover per transect, across sites. The dotted line indicates the simple linear regression analysis

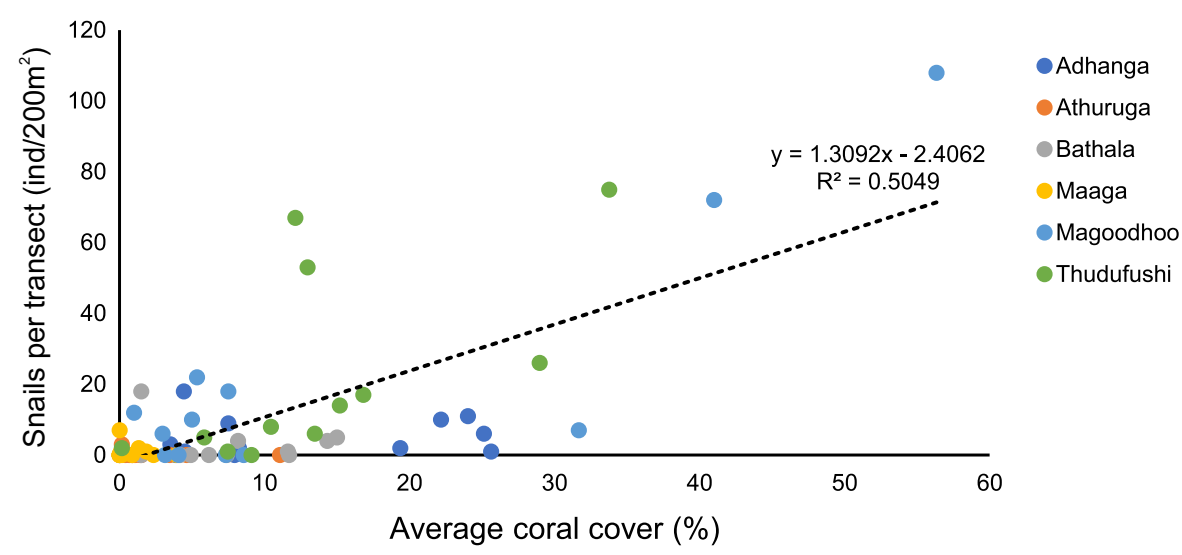

and recruits, with the presence of more than one generation as suggested by the dip test. In a scenario of limited resources, such as a decreased coral cover for food and shelter, aggregations may lead to intraspecific competition where size-dependent density tends to consist of the better competitors with large consequences on population dynamics (De Roos et al., 2003; De Roos \& Persson, 2013). In this case, adults may be considered as better competitors dominating the resource and hence causing juvenile mortality (Nicholson, 1954; May et al., 1974; Furness \& Birkhead, 1984). An additional explanation may be related to a lower rate of reproduction, as recruits were uncommon. Such limitations in reproduction may be caused by the reduction of substrate for egg capsule attachment. Drupella spp. lays egg capsules on the bare skeleton of corals (Sam et al., 2017; Scott et al., $2017 \mathrm{a}, \mathrm{b}$ ), but the reduction of prey presence and the increased competition with algae may lead to a reduction of space for the eggs and hence reduction in reproduction success.

Feeding behaviour

Drupella spp. was found feeding only on scleractinian corals which is in accordance with its ecology as an obligate corallivore (Morton et al., 2002; Rotjan \& Lewis, 2008). Few individuals were found on dead corals and coral rubble, probably moving in search for corals following scars or conspecific cues (Morton et al., 2002; Hamman, 2018).

The snails were aggregated mostly on branching corals, particularly of the genus Porites, followed by Pocillopora and Acropora, which also reflects the general prey preferences in the study area, apart from the genus Porites which resulted a random choice. In this study, looking at location scale, Drupella spp. feeding preferences changed following coral cover, with preference for Porites in locations with low coral cover such as Athuruga and Maaga, while Acropora and Pocillopora were preferred in locations with higher coral cover such as Thudufushi and Magoodhoo. It is known that acroporids are the favourite prey of Drupella spp. (Moyer et al., 1982; Fujioka \& Yamazato, 1983; Turner, 1994a, b; Cumming, 1999; Morton et al., 2002; Al-Horani et al., 2011), however, prey preferences may change according to the availability of corals. In Thailand, Drupella spp. was reported to shift from acroporids to fungiid corals following a temperature-induced coral mortality event (Hoeksema et al., 2013; Moerland et al., 2016). Also, in the Maldives, the snail was found extending the prey range from Acropora and Pocillopora to more than 10 genera, including Porites, in the aftermath of the 2016 bleaching event (Bruckner et al., 2017). However, we found the snail occupying only five coral genera, likely due to the highest mortality of other genera which may have different susceptibility to heat waves (Pisapia et al., 2016, 2019) and the slower recovery from the mortality event (Pisapia et al., 2016).

Spatial distribution

The population of Drupella spp. was monitored and documented around 2 years after the 2016 large scale coral bleaching event. In this study, the total mean density of Drupella spp. was much lower than in other studies (e.g. Ayling \& Ayling, 1987; Turner, 1994a, b; Al-Moghrabi, 1997; Cumming, 1999, 2009a, b; 
Bruckner et al., 2017). Notably, it was around 70-fold less than the density reported by Bruckner et al. (2017), in South Malé Atoll in $2016\left(0.045 \mathrm{ind} / \mathrm{m}^{2}\right.$ in this study, against $3.4 \mathrm{ind} / \mathrm{m}^{2}$ from Bruckner et al., 2017). This result suggests a possible collapse of Drupella spp. population in the aftermath of the bleaching event. Furthermore, no outbreak was reported as the mean density never exceeded the outbreak threshold of $>2 \mathrm{ind} / \mathrm{m}^{2}$ defined by Cumming $(2009 a, b)$. Mean density was lower than the level of $0.62 \mathrm{ind} / \mathrm{m}^{2}$ suggested by Bessey et al. (2018) as the density beyond which consumption of prey is faster than its growth rate (specifically for Acropora spicifera).

Although not in outbreak, the population showed the presence of mainly small aggregations, most of which were found in locations (Magoodhoo and Thudufushi) with the highest coral cover. These sites also had the largest snails observed during the study. Such findings is in accordance with the theory of optimal foraging, which predicts that predators will aggregate most likely in areas with high prey density (see Cumming, 2009a). Generally, the number of aggregations and the individuals per aggregation were lower compared to other studies (Cumming 2009a, b) and especially compared to the findings of Bruckner et al. (2017) who reported aggregations of up to 250 individuals on a single coral colony in South Malé Atoll, Maldives.

It is possible that the population of Drupella spp. has decreased compared to the findings of Bruckner et al. (2017). The reduction in live corals caused by the bleaching event in 2016 may have influenced population dynamics of the snail which uses coral colonies as food and shelter (e.g. Ayling \& Ayling, 1987; Hamman, 2018). On the other hand, there is evidence that coral predators showing dietary plasticity, like other gastropods and fishes, may prey more heavily on remaining corals (see Pratchett et al., 2004; Cole et al., 2009; Hoeksema et al., 2013; Tsang \& Ang, 2014; Zambre \& Arthur, 2018). Thus, even if the population was apparently decreased, the dietary plasticity may have pushed the snails to aggregate on remaining corals, increasing local predation pressure. Drupella spp. may have even moved to deeper areas of the reef looking for live corals, since the shallow reef was more exposed to the bleaching event, and thus may have had the highest coral mortality (Pisapia et al., 2016, 2019), although more research is needed to clarify this aspect. Additionally, in response to temperature-induced coral mortality, the snails may be more exposed to predators (Hamman, 2018) and to population decline as also reported for other obligate corallivores such as the coral-dwelling crab Trapezia cymodoce (Herbst, 1801) (Stella et al., 2011), butterflyfish (Graham et al., 2009), the filefish Oxymonacanthus longirostris (Bloch and Schneider, 1801) (Hobbs et al., 2010) and other coral-dependent fish (Booth \& Beretta, 2002).

The snail was homogeneously distributed along the surveyed area at atolls (Ari and Faafu) and the reef scale. Contrarily, differences were found when comparing localities, likely because coral cover was differently affected by coral bleaching in 2016 in different localities (Pisapia et al., 2019). Generally, the density of Drupella spp. was higher in locations with higher coral cover, such as in Magoodhoo and Thudufushi, independently from the number of genera. The variability in Drupella spp. density was probably due to the plasticity in shifting feeding preferences according to the availability of coral genera.

Drupella spp. is likely to reduce resilience of live corals when acting synergically with other stressors, including temperature-induced mortality, diseases, pollution or other corallivores (e.g. Nicolet et al., 2013, 2018; Bruckner et al., 2017; Scott et al., 2017a, b; Shaver et al., 2018). In addition, cooccurrence of Drupella spp. with other corallivores was noted during an ongoing survey (pers. comm.) looking at the presence of three major corallivores in Maldives after the bleaching event in 2016 (the seastars Acanthaster planci and Culcita spp. and the gastropod Coralliophila spp.).

In this study, we showed that 2 years after the coral mortality event, the influence of Drupella spp. may be considered lower, possibly due to the collapse of the population. Furthermore, the majority of the corals preyed upon were only partially damaged $(<50 \%)$ at the time of the surveys, indicating a lower effect on coral cover. In this condition, the presence of coral guards such as Trapezia cymodoce (Samsuri et al., 2018) or the presence of deterring hydrozoans (Montano et al., 2017) may also reduce the predatory pressure, although further research is needed to verify this mechanism. In addition, no coral recruits were preyed upon, despite their presence, indicating that reef recovery is on-going. 


\section{Conclusions}

Drupella spp. showed a large-scale homogeneity in density and only showed variation dependent on coral cover at the site scale. The population collapsed and showed less aggregations around 2 years after the coral bleaching event in the study area, compared to previous reports in the Maldives. The consequent reduction in predatory pressure may enhance Maldivian reefs resilience, unless other factors will threaten coral survival. Further research should focus on larger geographical areas, including other atolls both in the north and in the south of Maldives and expand to deeper areas of the reef to have a better overview of the snail's spatial distribution. In addition, snail behaviour should be monitored including reefs with pre-bleaching coral cover to clarify the predatory activity and quantify the impacts with a focus on the co-occurrence with other corallivores in the Maldives.

Acknowledgements This research was supported by the Planhotel Hospitality Group. The authors wish to thank all the staff of Diamonds Athuruga and Thudufushi Resorts and Sandies Bathala, the staff from IDive Maldives Diving Center and the Ministry of the Fisheries and Agriculture, Republic of Maldives, for the logistical support provided. Finally, we are extremely grateful to the editor and reviewer for the constructive comments and suggestions.

Author contributions All authors contributed equally to the manuscript. All authors read and approved the manuscript.

Funding Open access funding provided by Università degli Studi di Milano - Bicocca within the CRUI-CARE Agreement.

Data availability The datasets generated during and/or analysed during the current study are available from the corresponding author on reasonable request.

Sampling and field studies All necessary permits for sampling and observational field studies have been obtained by the authors from the competent authorities and are mentioned in the acknowledgements, if applicable.

\section{Compliance with ethical standards}

Conflict of interest The authors declare that they have no conflict of interest.

Ethical approval All applicable international, national and/or institutional guidelines for the care and use of animals were followed by the authors.
Open Access This article is licensed under a Creative Commons Attribution 4.0 International License, which permits use, sharing, adaptation, distribution and reproduction in any medium or format, as long as you give appropriate credit to the original author(s) and the source, provide a link to the Creative Commons licence, and indicate if changes were made. The images or other third party material in this article are included in the article's Creative Commons licence, unless indicated otherwise in a credit line to the material. If material is not included in the article's Creative Commons licence and your intended use is not permitted by statutory regulation or exceeds the permitted use, you will need to obtain permission directly from the copyright holder. To view a copy of this licence, visit http://creativecommons.org/licenses/by/4.0/.

\section{References}

Al-Horani, F.A., M. Hamdi \& S. A. Al-Rousan, 2011. Prey selection and feeding rates of Drupella cornus (Gastropoda: Muricidae) on corals from the Jordanian coast of the Gulf of Aqaba, Red Sea. Jordan Journal of Biological Science 4: 191-198.

Al-Moghrabi, S. M., 1997. Bathymetric distribution of Drupella cornus and Coralliophila neritoidea in the Gulf of Aqaba (Jordan). In Proceedings of the 8th International Coral Reef Symposium, Vol. 2: 1345-1350.

Ayling, A. M. \& A. L. Ayling, 1987. Ningaloo Marine Park: Preliminary Fish Density Assessment and Habitat Survey: With Information on Coral Damage Due to Drupella cornus Grazing. Department of Conservation and Land Management, Western Australia: 47.

Antonious, A. \& B. Riegel, 1998. Coral diseases and Drupella cornus invasion in the Red Sea. Coral Reefs 17: 48.

Bessey, C., R. C. Babcock, D. P. Thomson \& M. D. E. Haywood, 2018. Outbreak densities of the coral predator Drupella in relation to in situ Acropora growth rates on Ningaloo Reef, Western Australia. Coral Reefs 37: 985-993.

Booth, D. J. \& G. A. Beretta, 2002. Changes in a fish assemblage after a coral bleaching event. Marine Ecology Progress Series 245: 205-212.

Brown, K. T., D. Bender-Champ, D. E. P. Bryant, S. Dove \& O. Hoegh-Guldberg, 2017. Human activities influence benthic community structure and the composition of the coral-algal interactions in the central Maldives. Journal of Experimental Marine Biology and Ecology 497: 33-40

Bruckner, A. W., G. Coward, K. Bimson \& T. Rattanawongwan, 2017. Predation by feeding aggregations of Drupella spp. inhibits the recovery of reefs damaged by mass bleaching event. Coral Reefs 36: 1181-1187.

Bruckner, A. W. \& G. Coward, 2018. Abnormal density of Culcita schmideliana delays recovery of a reef system in the Maldives following a catastrophic bleaching event. Marine and Freshwater Research. https://doi.org/10.1071/ MF18184.

Claremont, M., D. G. Reid \& S. T. Williams, 2011. Evolution of corallivory in the gastropod genus Drupella. Coral Reefs 30: 977-990. 
Cole, A. J., M. S. Pratchett \& G. P. Jones, 2009. Effects of coral bleaching on the feeding response of two species of coralfeeding fish. Journal of experimental Marine Biology and Ecology 373(1): 11-15

Cumming, R. L., 1999. Predation on reef-building corals: multiscale variation in the density of three corallivorous gastropods, Drupella spp. Coral Reefs 18: 147-157.

Cumming, R. L., 2009a. Population Outbreaks and Large Aggregations of Drupella on the Great Barrier. Reef Research Publication 96. Great Barrier Reef Marine Park Authority, Townsville.

Cumming, R. L., 2009b. Case Study: Impact of Drupella spp. on Reef-Building Corals of the Great Barrier Reef. Research Publication 97, Great Barrier Reef Marine Park Authority, Townsville.

De'ath, G., K. E. Fabricius, H. Sweatman \& M. Puotinen, 2012. The 27-year decline of coral cover on the Great Barrier Reef and its causes. Proceedings of the National Academy of Sciences of USA [available on internet at https://doi.org/ 10.1073/pnas.1208909109].

De Roos, A. M., L. Persson, \& E. McCauley, 2003. The influence of size-dependent life-history traits on the structure and dynamics of populations and communities. Ecology Letters 6: 473-487

De Roos, A. M. \& L. Persson, 2013. Population and Community Ecology of Ontogenetic Development. Princeton: Princeton University Press.

Fallati, L., A. Savini, S. Sterlacchini \& P. Galli, 2017. Land use and land cover (LULC) of the Republic of the Maldives: first national map and LULC change analysis using remotesensing data. Environment Monitoring and Assessment 189: 417.

Fujioka, Y. \& K. Yamazato, 1983. Host selection of some Okinawan coral associated gastropods belonging to the genera Drupella, Coralliophila and Quoyula. Galaxea 2: $59-73$.

Furness, R. \& T. Birkhead, 1984. Seabird colony distributions suggest competition for food supplies during the breeding season. Nature 311: 655-656.

Graham, N. A. J., S. K. Wilson, M. S. Pratchett, N. V. C. Polunin \& M. D. Spalding, 2009. Coral mortality versus structural collapse as drivers of corallivorous butterflyfish decline. Biodiversity and Conservation 18: 3325-3336.

Hamman, E. A., 2018. Aggregation patterns of two corallivorous snails and consequences for coral dynamics. Coral Reefs 37: 851-860.

Hartigan, J. A. \& P. M. Hartigan, 1985. The dip test of unimodality. Annals of Statistics 13(1): 70-84.

Hobbs, J. A., A. M. Ayling, H. Choat, J. J. Gilligan, C. A. McDonald, J. Neilson \& S. J. Newman, 2010. New records of marine fishes illustrate the biogeography importance of Christmas Island, Indian Ocean. Zootaxa 2422: 63-68.

Hoegh-Guldberg, O., E. S. Poloczanska, W. Skirving \& S. Dove, 2017. Coral reef ecosystems under climate change and ocean acidification. Frontiers in Marine Science. https://doi.org/10.3389/fmars.2017.00158.

Hoeksema, B. W., C. Scott \& J. D. True, 2013. Dietary shift in corallivorous Drupella snails following a major bleaching event at Koh Tao, Gulf of Thailand. Coral Reefs 32: 423-428.
Hughes, T. P., M. L. Barnes, D. R. Bellwood, J. E. Cinner, G. S. Cumming, J. B. C. Jackson, J. Kleypas, et al. 2017a. Coral reefs in the Anthropocene. Nature, 546: 82-90.

Hughes, T. P., J. T. Kerry, M. Álvarez-Noriega, J. G. ÁlvarezRomero, K. D. Anderson, A. H. Baird, R. C. Babcock, et al., 2017b. Global warming and recurrent mass bleaching of corals. Nature 543: 373-377.

Ivlev, V. S., 1961. Experimental Ecology of the Feeding of Fishes. Yale University Press, New Haven: 302.

Koido, T., Y. Oku, M. Fukuda, A. Nakano \& H. Fukami, 2017. Drupella outbreak in a large coral community off the coast of Cape Toi, Miyazaki, Japan. Galaxea 19: 31-32.

Lam, K. \& P. K. S. Shin, 2007. Severe bioerosion caused by an outbreak of corallivorous Drupella and Diadema at Hoi Ha Wan Marine Park, Hong Kong. Coral Reefs 26: 893.

Maechler, M., 2016. Diptest: Hartigan's Dip Test Statistic for Unimodality - Corrected. R Package Version 0.75-7 [available on internet at https://CRAN.R-project.org/ package $=$ diptest $]$.

May, R., G. Conway, M. Hassell \& T. Southwood, 1974. Time delays, density-dependence and single-species oscillations. Journal of Animal Ecology 3: 747-770.

Marimuthu, N. \& B. Tripathy, 2018. First report of Drupella cornus Röding, 1798 (Gastropoda: Muricidae), a biological indicator of coral reef habitat of Lakshadweep Archipelago, India. Record of the Zoological Survey of India 118(1): 97-99.

McClanahan, T. R., 1994. Coral-eating snail Drupella cornus population increases in Kenyan coral reef lagoons. Marine Ecology Progress Series 115: 131-137.

McClanahan, T. R., 1997. Dynamics of Drupella cornus populations on Kenyan coral reefs. In Proceedings of the 8th International Coral Reef Symposium, Vol. 1: 633-638.

McClanahan, T. T. \& N. A. Muthiga, 2014. Community change and evidence for variable warm-water temperature adaptation of corals in Northern Male Atoll, Maldives. Marine Pollution Bulletin 80: 107-113.

Moerland, M. S., C. M. Scott \& B. W. Hoeksema, 2016. Prey selection of corallivorous muricids at Koh Tao (Gulf of Thailand) 4 years after a major coral bleaching event. Contributions to Zoology 85: 291-309.

Montalbetti, E., L. Saponari, S. Montano, D. Maggioni, I. Dehnert, P. Galli \& D. Seveso, 2019a. New insights into the ecology and corallivory of Culcita sp. (Echinodermata: Asteroidea) in the Republic of Maldives. Hydrobiologia 827: 353-365.

Montalbetti, E., L. Saponari, S. Montano \& D. Seveso, 2019 b. Another diner sits at the banquet: evidence of a possible population outbreak of Culcita sp. (Agassiz, 1836) in Maldives. Galaxea 21: 5-6.

Montano, S., G. Strona, D. Seveso \& P. Galli, 2012. First report of coral diseases in the Republic of Maldives. Diseases of Aquatic Organisms 101: 159-165.

Montano, S., A. Giorgi, M. Monti, D. Seveso \& P. Galli, 2016. Spatial variability in distribution and prevalence of skeletal eroding band and brown band disease in Faafu Atoll, Maldives. Biodiversity and Conservation 25(9): 1625-1636.

Montano, S., G. Strona, D. Seveso, D. Maggioni \& P. Galli, 2015a. Widespread occurrence of coral diseases in the 
central Maldives. Marine and Freshwater Research 67(8): 1253-1262.

Montano, S., G. Strona, D. Seveso, D. Maggioni \& P. Galli, 2015b. Slow progression of black band disease in Goniopora cf. columna colonies may promote its persistence in a coral community. Marine Biodiversity 45: 857-860.

Montano, S., S. Fattorini, V. Parravicini, M. L. Berumen, P. Galli, D. Maggioni, R. Arrigoni, D. Seveso \& G. Strona, 2017. Corals hosting symbiotic hydrozoans are less susceptible to predation and disease. Proceedings of Royal Society B: Biological Sciences 284: 20172405.

Morton, B., G. Blackmore \& C. T. Kwok, 2002. Corallivory and prey choice by Drupella rugosa (Gastropoda: Muricidae) in Hong Kong. Journal of Molluscan Studies 68: 217-223.

Morton, B. \& G. Blackmore, 2009. Seasonal variations in the density of and corallivory by Drupella rugosa and Cronia margariticola (Caenogastropoda: Muricidae) from the coastal waters from Hong Kong: 'plagues' or 'aggregations'? Journal of the Marine Biological Association of the U.K. 89: 147-159.

Moyer, J. T., W. K. Emerson \& M. Ross, 1982. Massive destruction of scleractinian corals by the muricid gastropod Drupella in Japan and the Philippines. Nautilus 96: 69-82.

Nicolet, K. J., M. O. Hoogenboom, N. M. Gardiner, M. S. Pratchett \& B. L. Willis, 2013. The corallivorous invertebrate Drupella aids in transmission of brown band disease on the Great Barrier Reef. Coral Reefs 32: 585-595.

Nicolet, K. J., K. M. Chong-Seng, M. S. Pratchett, B. L. Willis \& M. O. Hoogenboom, 2018. Predation scars may influence host susceptibility to pathogens: evaluating the role of corallivores as vectors of coral disease. Scientific Reports 8: 5258.

Nicholson, A., 1954. An outline of the dynamics of animal populations. Australian Journal of Zoology 2: 9-65.

Perry, C. T., \& K. M. Morgan, 2017. Bleaching drives collapse in reef carbonate budgets and reef growth potential on southern Maldives reefs. Nature 7: 40581.

Pisapia, C., D. Burn, R. Yoosuf, A. Najeeb, K. D. Anderson \& M. S. Pratchett, 2016. Coral recovery in the central Maldives Archipelago since the last major mass-bleaching, in 1998. Science Reports 6: 34720.

Pisapia, C., D. Burn \& M. S. Pratchett, 2019. Changes in the population and community structure of corals during recent disturbances (February 2016-October 2017) on Maldivian coral reefs. Science Reports 9:8402.

Pratchett, M. S., S. K. Wilson, M. L. Berumen \& M. I. McCormick, 2004. Sublethal effects of coral bleaching on an obligate coral feeding butterflyfish. Coral Reefs 23 : 352-356.

Pratchett, M. S., C. F. Caballes, J. A. Rivera-Posada \& H. P. Sweatman, 2014. Limits to understanding and managing outbreaks of crown-of-thorns starfish (Acanthaster spp.). Oceanography and Marine Biology 52: 133-200.

Pratchett, M. S., C. F. Caballes, J. C. Wilmes, S. Matthews, C. Mellin, H. P. A. Sweatman, L. Nadler, J. Brodie, C. A. Thompson, J. Hoey, A. R. Bos, M. Byrne, V. Messmer, S. A. V. Fortunato, C. C. M. Chen, A. C. E. Buck, R. C. Babcock \& S. Uthicke, 2017. Thirty years of research on Crown-of-Thorns starfish (1986-2016): scientific advance and emerging opportunities. Diversity 9(4): 41.
R Core Team, 2017 R: A Language and Environment for Statistical Computing. R Foundation for Statistical Computing, Vienna [available on internet at https://www.Rproject.org/].

Ratianingsih, R., N. Ismawati, J. W. Puspita \& A. I. Jaya, 2017. The role of top-predator in the preservation of coral reefs ecosystem. Communications in Mathematical Science 1: 54-61.

Rice, M. M., L. Ezzat \& D. E. Burkepile, 2019. Corallivory in the Anthropocene: interactive effects of Anthropogenic stressors and corallivory on coral reefs. Frontiers in Marine Science. https://doi.org/10.3389/fmars.2018.00525.

Rotjan, R. D. \& S. M. Lewis, 2008. Impact of coral predators on tropical reefs. Marine Ecology Progress Series 367: 73-91.

Sam, S. Q., T. C. Toh, Y. P. Kikuzawa, C. S. L. Ng, D. Taira, L. Afiq-Rosli, K. S. Tan \& L. M. Chou, 2017. Egg capsules and veligers of the corallivorous muricid gastropod Drupella rugosa (Born, 1778). Invertebrate Reproduction and Development 61(3): 167-171.

Samsuri, A. N., Y. P. Kikusawa, D. Taira, S. Q. Sam, W. T. Sim, C. S. L. Ng, L. Afiq-Rosil, T. W. D. Wee, N. K. Ng, T. C. Toh \& L. M. Chou, 2018. The effectiveness of Trapezia cymodoce in defending its host coral Pocillopora acuta against corallivorous Drupella. Marie Biology 165: 70.

Saponari, L., S. Montano, D. Seveso \& P. Galli, 2014. The occurrence of an Acanthaster planci outbreak in Ari Atoll, Maldives. Marine Biodiversity. https://doi.org/10.1007/ s12526-014-0276-6.

Saponari, L., E. Montalbetti, P. Galli, G. Strona, D. Seveso, I. Dehnert \& S. Montano, 2018. Monitoring and assessing a 2-year outbreak of the corallivorous seastar Acanthaster planci in Ari Atoll, Republic of Maldives. Environmental and Monitoring Assessment 190: 344.

Scott, C. M., R. Mehrotra, M. Y. Hein, M. S. Moerland \& B. W. Hoeksema, 2017a. Population dynamics of corallivores (Drupella and Acanthaster) on coral reefs of Koh Tao, a diving destination in the Gulf of Thailand. The Raffles Bulletin of Zoology 65: 68-79.

Scott, C. M., R. Mehrotra \& B. W. Hoeksema, 2017b. In-situ egg deposition by corallivorous snails on mushroom corals at Koh Tao (Gulf of Thailand). Journal of Molluscan Studies 83: 360-362.

Seveso, D., S. Montano, G. Strona, I. Orlandi, M. Vai \& P. Galli, 2012. Up-regulation of Hsp60 in response to skeleton eroding band disease but not by algal overgrowth in the scleractinian coral Acropora muricata. Marine Environmental Research 78: 34-39.

Shaver, E. C., D. E. Burkepile \& B. R. Silliman, 2018. Local management actions can increase coral resilience to thermally-induced bleaching. Nature Ecology and Evolution 2: 1075-1079.

Stella, J. S., P. L. Munday \& G. P. Jones, 2011. Effects of coral bleaching on the obligate coral-dwelling crab Trapezia cymodoce. Coral Reefs 30: 719-727.

Williams, G. J., N. A. J. Graham, J.-B. Jouffray, A. V. Norström, M. Nyström, J. M. Gove, A. Heenan \& L. M. Wedding, 2019. Coral reef ecology in the Anthropocene. Functional Ecology. https://doi.org/10.1111/1365-2435.13290.

Woodhead, A. J., C. C. Hicks, A. V. Norström, G. J. Williams \& N. A. J. Graham, 2019. Coral reef ecosystem services in the 
Anthropocene. Functional Ecology. https://doi.org/10. 1111/1365-2435.13331.

Taylor, J. D., 1978. Habitats and diet of predatory gastropods at Addu Atoll, Maldives. Journal of Experimental Marine Biology and Ecology 31: 83-103.

Tsang, R. H. L. \& P. J. Ang, 2014. Cold temperature stress and predation effects on corals: their possible roles in structuring a nonreefal coral community. Coral Reefs 34(1): 97-108.

Turner, S. J., 1994a. Spatial variability in the abundance of the corallivorous gastropod Drupella cornus. Coral Reefs 13: $41-48$.

Turner, S. J., 1994b. The biology and population outbreaks of the corallivorous gastropod Drupella on Indo-Pacific reefs. In Oceanography and Marine Biology: An Annual Review,
Vol. 32. Aberdeen University Press/Allen and Unwin, London: 461-530.

Zahir, H., 2000. Status of the coral reefs of Maldives after the bleaching event in 1998. In Souter, D., D. Obura \& O. Lindén (eds), Coral Reef Degradation in the Indian Ocean. Cordio, Stockholm: 64-68.

Zambre, A. M. \& R. Arthur, 2018. Foraging plasticity in obligate corallivorous Melon butterflyfish across three recently bleached reefs. Ethology 124(5): 302-310.

Zar, J. H., 1999. Biostatistical Analysis. Prentice-Hall, London.

Publisher's Note Springer Nature remains neutral with regard to jurisdictional claims in published maps and institutional affiliations. 